\title{
Intracolonial variation in Siderastrea de Blainville, 1830 (Anthozoa, Scleractinia): taxonomy under challenging morphological constraints
}

\author{
Natália Matos de Menezes ${ }^{1,4}$, Elizabeth Gerardo Neves ${ }^{1}$, Francisco Barros², \\ Ruy Kenji Papa de Kikuchi ${ }^{3}$ \& Rodrigo Johnsson ${ }^{1}$ \\ ${ }^{1}$ Laboratório de Invertebrados Marinhos: Crustacea, Cnidaria e Fauna Associada - LABIMAR, \\ Departamento de Zoologia, Instituto de Biologia, Universidade Federal da Bahia - UFBA, \\ Rua Barão de Geremoabo, 147, Campus Ondina, CEP 40170-290, Salvador, BA, Brasil \\ ${ }^{2}$ Laboratório de Ecologia Bentônica, Departamento de Zoologia, Instituto de Biologia, \\ Universidade Federal da Bahia - UFBA, Rua Barão de Geremoabo, 147, \\ Campus Ondina, CEP 40170-290, Salvador, BA, Brasil \\ ${ }^{3}$ Grupo de Pesquisa em Recifes de Corais e Mudanças Globais, Departamento de Sedimentologia, \\ Instituto de Geociências, Universidade Federal da Bahia - UFBA, Rua Barão de Geremoabo, s/n, \\ Campus Ondina, CEP 40170-290, Salvador, BA, Brasil \\ ${ }^{4}$ Corresponding author: Natalia Matos de Menezes, e-mail: menezes.natalia@gmail.com
}

MENEZES, N.M., NEVES, E.G., BARROS, F., KIKUCHI, R.K.P. \& JOHNSSON, R. Intracolonial variation in Siderastrea de Blainville (Anthozoa, Scleractinia): taxonomy under challenging morphological constraints. Biota Neotrop. 13(1): http://www.biotaneotropica.org.br/v13n1/en/abstract?article+bn02513012013

\begin{abstract}
The morphology of sessile invertebrates, such as scleractinian corals, can be controlled by environmental and genetic mechanisms and, consequently, it is highly variable. Morphological variation has puzzled taxonomists by posing challenges to species classification within cryptic species complexes. The 'Atlantic Siderastrea Complex' is a suitable example. Because of overlapping diagnostic traits, the morphological interspecific limits of this group remain controversial and often resulted in doubtful synonyms. In addition, the recent identification of the Caribbean S. radians in the Southwestern Atlantic has revealed that intraspecific variation has been equivocally assessed. Traditionally, hierarchical categories of variation have been the criteria used to investigate the patterns of modular organisms as corals. However, despite its taxonomic and ecological implications, the category 'intracolonial' has been largely neglected. To evaluate the influences of intracolonial morphological variation in the identification of Atlantic siderastreids, colonies from Bahia State, northeastern Brazil, were collected and measured. Six characters were selected in S. radians and S. stellata, and the variation in these characters was analyzed with Discriminant Canonical Analysis. The columellar depth and diameter varied consistently within S. stellata and S. radians, but the septal number was the most important for differentiating the two species. The results of the study also represent the first report of $S$. radians on the northern coast of Bahia.
\end{abstract}

Keywords: systematics, Siderastrea radians, morphological variation, biogeographic expansion, South Atlantic.

MENEZES, N.M., NEVES, E.G., BARROS, F., KIKUCHI, R.K.P. \& JOHNSSON, R. Variação intracolonial em Siderastrea de Blainville (Anthozoa, Scleractinia): taxonomia sob limites morfológicos desafiadores. Biota Neotrop. 13(1): http://www.biotaneotropica.org.br/v13n1/pt/abstract?article+bn02513012013

Resumo: A morfologia de invertebrados sésseis, tais como corais escleractíneos, é controlada por mecanismos genéticos e ambientais e, por conseguinte, é muito variável. Entretanto, variação morfológica tem intrigado os taxonomistas principalmente por desafiar a identificação de complexos de espécies crípticas. O "Complexo Siderastrea do Atlântico” é um exemplo desta problemática. Por conta da sobreposição dos traços diagnósticos, os limites morfológicos interespecíficos deste grupo permanecem controversos e muitas vezes resultaram em sinonímias de interpretação duvidosa. Além disso, a recente identificação do S. radians para o Atlântico Sul revelou que a variação intra-específica tem sido avaliada equivocadamente. Tradicionalmente, categorias hierárquicas de variação são os critérios mais utilizados para investigar os padrões de organismos modulares como corais. No entanto, apesar de sua importância taxonômica e ecológica, a categoria "intracolonial" tem sido amplamente negligenciada. No sentido de elucidar a influencia de variação morfológica intracolonial na identificação do gênero Siderastrea, colônias do Estado da Bahia, nordeste do Brasil, foram coletadas e medidas. Seis características foram selecionadas em $S$. radians e $S$. stellata, e a variação destas características foi analisada através da Análise Discriminante Canônica. A profundidade e diâmetro columelar variaram de forma consistente dentro de $S$. stellata e $S$. radians, mas o número de septos foi o mais importante para diferenciar as duas espécies. Por fim, o estudo também provê o primeiro relato de $S$. radians no litoral norte da Bahia.

Palavras-chave: sistemática, Siderastrea radians, variação morfológica, expansão biogeográfica, Atlântico Sul. 


\section{Introduction}

The morphology of sessile invertebrates, such as scleractinian corals, can be highly variable because it is controlled by both environmental and genetic mechanisms (Best \& Winston 1984, Veron 1995, Lombardi et al. 2008). In the case of the zooxanthellate reef building corals, intraspecific variation may be regulated by the processes of adaptation to habitat heterogeneity, interpopulation genetic connectivity (or long-term isolation), and/or local selection (Gattuso et al. 1991). Because of this, some widely distributed coral genera are represented by 'species complexes' with demes consisting of miscellaneous variable morphs and undistinguishable cryptic forms that limits the traditional taxonomic methods of morphological analyses (sensu Weil \& Knowlton 1994). Considering the modular characteristics in the development of scleractinian corals (Hageman 2003), taxonomists have suggested the analysis of intracolonial, intrapopulational, and interpopulational levels of variation to support identifications (Best et al. 1983, Miller 1994, Veron 1995). Intracolonial variability, in specific, apparently occurs on a 'microecological' scale (or in a microenvironment) and might reach extreme levels in cases where distinct parts of the same colony have corallites with the characteristics of different genera (Best et al. 1983, Veron 1995). However, despite the overall implications for population approaches, only a few studies have concisely considered the variation within coral colonies (Land et al. 1975, Foster 1985).

Siderastrea is a suitable example of controversial morphologic limits among species and doubtful synonyms. The genus is widespread in reef systems and coral communities from the Caribbean to tropical southwestern America, extending to western Africa (Verrill 1868, Buchanan 1954, Chevalier 1966, Laborel 1974, 1969/70, Leão 1986, Fenner 1993, Chiappone et al. 1996, Neves \& Da Silveira 2003). It is also represented for massive colonies, known by its high capacity of resilience and frequency in shallow-water habitats (Laborel 1967, 1969/70, Zlatarski \& Estalella 1982, Holst \& Gúzman 1993, Maida \& Ferreira 1997). The 'Atlantic Siderastrea Complex’ comprises three species, Siderastrea radians and Siderastrea siderea, commonly known as Caribbean species, and Siderastrea stellata, endemic from Brazilian coast and distributed from Maranhão to Rio de Janeiro states (Laborel 1969/70, Leão 1986, Maida \& Ferreira 1997, Castro \& Pires 2001, Couto et al. 2003, Neves et al. 2006, Amaral et al. 2007). Consistent differences in the patterns of reproduction have successfully distinguished the broadcast spawner $S$. siderea from the brooders S. radians and S. stellata (Szmant 1986, Neves \& Da Silveira 2003). Genetic structure, in turn, has been reported to differentiate $S$. radians form S. stellata (Neves et al. 2008). However, morphological differences between these species are still not well understood.

In Brazil, analyses based on numerical methods have been conducted for the first time by Amaral (1994) to assess morphological population variability in Montastraea cavernosa. Data from the genus Siderastrea was initially provided by Werner (1996) and Santos et al. (2004). The former study is biased by the endemism of the Brazilian coral fauna, whereas the latter is biased by the similarities among Atlantic siderastreids. According to Werner (1996), for instance, $S$. stellata should be regarded as a synonym of $S$. radians. However, through genetic and biological analyses, Neves \& Da Silveira (2003), Neves (2004) and Neves et al. (2008) have refuted all synonymies, revealing the sympatric occurrence of $S$. radians and $S$. stellata populations in Brazil. Thus, the traditional view of the 'excess of morphological variation' for Southwestern Atlantic Siderastrea has possibly been attributed to the co-occurrence of both congeners and not exclusively $S$. stellata. In addition, none of the studies op. cit. considers the intracolonial variation of each species. As emphasized by Foster (1980), who estimated high intracolonial variation for
S. siderea in Caribbean reefs, within-colony variation may be used to predict the magnitude of within-population and within-species variation and should be considered in morphological studies.

In the present study, numerical methods are utilized to analyze corallite characters and evaluate the magnitude of variation within and among colonies of $S$. stellata and S. radians from Brazilian reef systems and coral communities. The results of the study are expected to provide further refinements in the delimitation of the Atlantic Siderastrea and contribute to the current knowledge of variability among scleractinians and the patterns that underlie the maintenance of the species boundaries.

\section{Materials and Methods}

\section{Study area}

Sampling was performed in two distinct geographical areas of Bahia State (northeastern Brazil): the coastal bay 'Baía de Todosos-Santos' (BTS) and the north shore (NS) (Figure 1). Situated between $12^{\circ}$ and $13^{\circ}$ latitude south of the Equator, with an area of approximately 1,200 $\mathrm{km}^{2}$ and containing 91 islands, the BTS is the second-largest bay in Brazil (Cirano \& Lessa 2007). Despite its ecological importance and poorly known biodiversity, the bay has been critically impacted by increasing euthrophication, chemical and solid pollution, land runoff, sedimentation, and overexploitation of the natural resources (Celino \& Queiroz 2006, Amado-Filho et al. 2008, Felizzola et al. 2008). Along the north coast (NS) of Bahia State, discontinuous coral reefs extend for approximately $20 \mathrm{~km}$ in very shallow waters. Superficial coral-algal reefs less than $1 \mathrm{~m}$ high are found above a line of beach rock, whereas drowned reefs occur in deeper environments at depths of 20 to 70 m (Kikuchi 2000). These systems, like the BTS, have been extensively exploited and show evidence of degradation (Costa et al. 2000).

\section{Sampling design}

Over a succession of periods from 2006 through 2008, a total of nine localities were selected for study: five around the BTS and four along the NS (Figure 1). The total number of species in each locality (n), the coordinates (lat/long), and additional information on the samples collected are shown in Table 1 . To avoid errors in taxonomy, no identification of $S$. stellata and $S$. radians was performed in the field. Therefore, a balanced number of samples (i.e., colonies) at each sampling site was difficult to achieve, especially in view of the sympatric distribution of the congeners. Colonies ranging from 3 to $10 \mathrm{~cm}$ in diameter were haphazardly collected at a minimum distance of $2 \mathrm{~m}$. This protocol was adopted in view of the philopatric pattern typically found among brooding corals. As previously described, $S$. stellata and $S$. radians exhibit a gregarious pattern during larval recruitment, with newly-settled larvae regularly undergoing fusion (see Duerden 1902, Neves \& Da Silveira 2003). Colonies with evidence of disease or physiological senescence (e.g., irregular pigmentation, blemishes, or whitening) were not collected. Samples were removed with a hammer and chisel from depths of 0 to $30 \mathrm{~cm}$ during low tide or by SCUBA diving in deeper tide pools (1 to $3 \mathrm{~m}$ ). In the laboratory, the colonies were bleached overnight in a solution of $2 \%$ sodium hypochlorite for analyses of the skeletal structures. A preliminary taxonomic identification of Siderastrea was performed on the basis of the number and conspicuity of the septal cycles in accordance with Neves (2004). The specific status of 156 specimens/colonies was determined. Morphometric data were collected with a stereomicroscope (NIKON, model SMZ1000) supplied with a calibrated eyepiece and a digital camera (NIKON, model COOLPIX 995). Corallum diameters were measured with a 


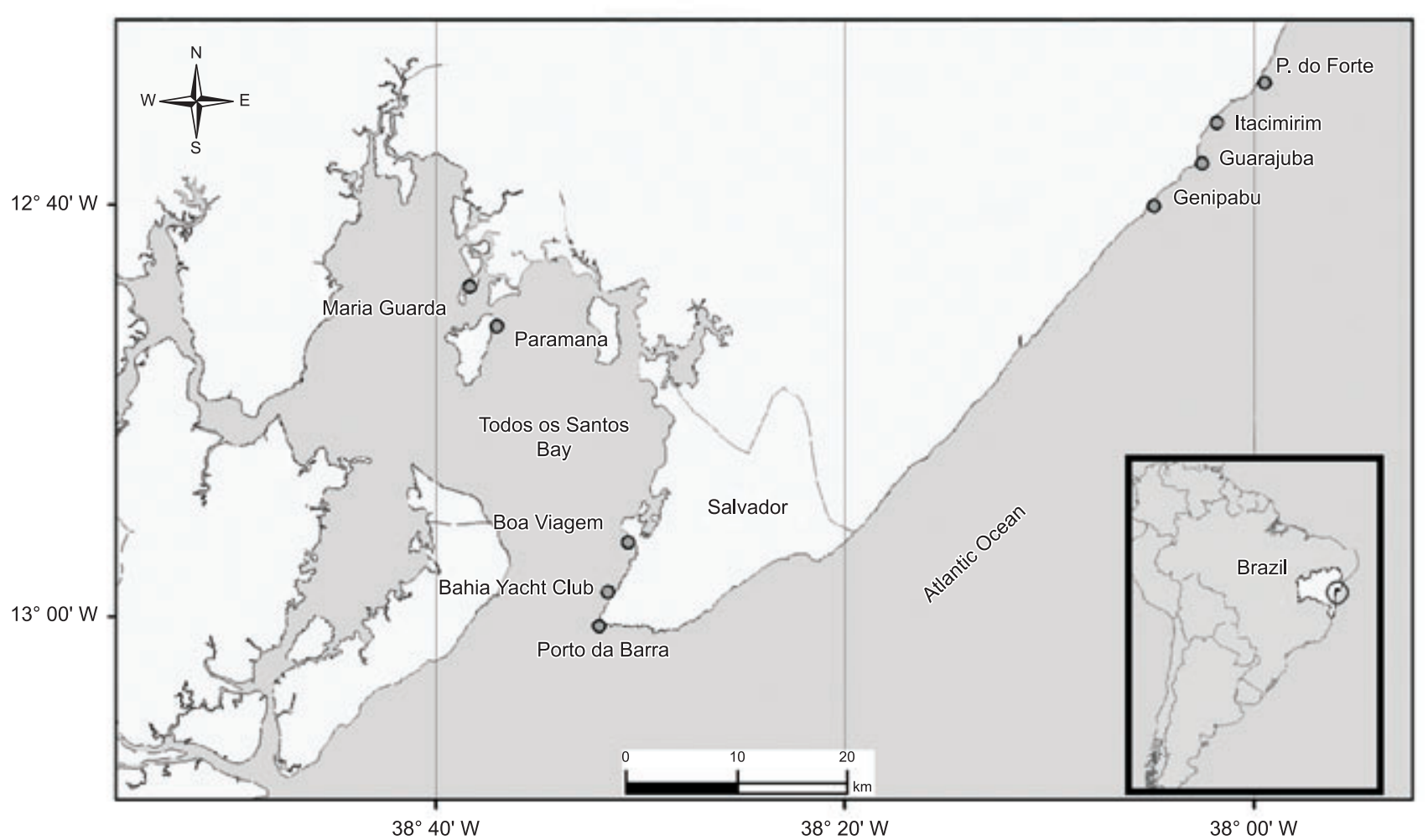

Figure 1. Map indicating study area and localities selected for sampling of Siderastrea colonies. Todos os Santos Bay (BTS)= Maria Guarda, Paramana, Boa Viagem, Bahia Yacht Club and Porto da Barra; North Shore (NS)= Genipabu, Guarajuba, Itacimirim and Praia do Forte.

Table 1. Detailed data on sampling locations within two major areas of Bahia State (northeastern Brazilian coast): Todos os Santos Bay (BTS) and the North Shore (NS). Lat/Long = georeferenced coordinates, $\operatorname{cols}(\mathrm{n})=$ number of colonies per locality $(\mathrm{Ss}=\mathrm{S}$. stellata, $\mathrm{Sr}=\mathrm{S}$. radians).

\begin{tabular}{|c|c|c|c|c|c|}
\hline Section & Localities & Lat/Long & \multicolumn{2}{|c|}{ Cols(n) } & Date \\
\hline \multirow[t]{5}{*}{ BTS } & Maria Guarda Island & $12^{\circ} 43^{\prime} \mathrm{S} / 38^{\circ} 38^{\prime} \mathrm{W}$ & Ss(15) & $\operatorname{Sr}(3)$ & $\begin{array}{l}20 \text { Aug } 05 \\
28 \text { Apr } 06\end{array}$ \\
\hline & Paramana beach & $12^{\circ} 45^{\prime} \mathrm{S} / 38^{\circ} 37^{\prime} \mathrm{W}$ & Ss(15) & $\operatorname{Sr}(12)$ & 28 Apr 06 \\
\hline & Boa Viagem beach & $12^{\circ} 56^{\prime} \mathrm{S} / 38^{\circ} 30^{\prime} \mathrm{W}$ & $\mathrm{Ss}(20)$ & - & 27 Apr 06 \\
\hline & Bahia Yacht Club & $12^{\circ} 59^{\prime} \mathrm{S} / 38^{\circ} 31^{\prime} \mathrm{W}$ & Ss(17) & - & 27 Apr 06 \\
\hline & Porto da Barra beach & $13^{\circ} 00^{\prime} \mathrm{S} / 38^{\circ} 32^{\prime} \mathrm{W}$ & Ss(14) & - & 24 Apr 06 \\
\hline \multirow[t]{4}{*}{ NS } & Genipabu-Abaí reef & $12^{\circ} 40^{\prime} \mathrm{S} / 38^{\circ} 05^{\prime} \mathrm{W}$ & Ss(15) & - & 20 Mar 07 \\
\hline & Guarajuba reef & $12^{\circ} 38^{\prime} \mathrm{S} / 38^{\circ} 03^{\prime} \mathrm{W}$ & $\operatorname{Ss}(12)$ & $\operatorname{Sr}(3)$ & $\begin{array}{l}23 \text { Nov } 06 \\
19 \text { Mar } 07\end{array}$ \\
\hline & Itacimirim reef & $12^{\circ} 36^{\prime} \mathrm{S} / 38^{\circ} 02^{\prime} \mathrm{W}$ & Ss(13) & $\operatorname{Sr}(2)$ & 12 Jan 08 \\
\hline & Praia do Forte reef & $12^{\circ} 34^{\prime} \mathrm{S} / 37^{\circ} 59^{\prime} \mathrm{W}$ & Ss(11) & $\operatorname{Sr}(4)$ & $\begin{array}{c}19 \text { Nov } 05 \\
04 \text { Nov } 06 \\
12 \text { Jan } 08\end{array}$ \\
\hline
\end{tabular}

MITUTOYO digital pachymeter. Specimens were catalogued and deposited in the Cnidaria Collection at the 'Museu de Zoologia da Universidade Federal da Bahia’ (acronym UFBA) as follows: BTS: Maria Guarda I. — UFBA 584, Paramana I. — UFBA 575, 576, 577, Boa Viagem — UFBA 578, 579, 594, 595, Iate Clube - UFBA 580, 581, 582, Porto da Barra — UFBA 583; NS: Genipabú-Abaí — UFBA 518, 519, 521, 522, 524, 529-532, 541, Itacimirim — UFBA 587, 632; Guarajuba — UFBA 536, 539, 562, Praia do Forte — UFBA $508,610,612,619,632$. Multiple colonies of the same population were deposited in separate lots.

\section{Measurements}

Only mature corallites ('old polyps' sensu Soong \& Lang 1992) with at least the third cycle of the septa fully formed were examined. For each colony, three distinct vertical zones were determined (top, middle and edge). From each of these zones, five corallites were selected for morphometric analyses. Because the morphology of the colonies varied from spherical to plate-encrusting forms, the following definitions were used to specify the vertical zones. The top zone was defined as the upper surface of the colony distal from 
the base, a flattened or dome-like area 1 to $3 \mathrm{~cm}$ in diameter. The edge was defined as the marginal area in contact with the substratum, including three and/or four corallite upper lines (the first of which was frequently buried in the sand). The middle was defined as the large area between the inner limits of the two previous zones. The diagnostic morphological variables were chosen according to the available literature (Milne Edwards \& Haime 1857, Verrill 1868, Vaughan 1919, Vaughan \& Wells 1943, Laborel 1967, 1969/70, Budd \& Gúzman 1994, Neves 2004, Foster 1977, 1979, 1980, 1985, Budd 1990). Six quantitative parameters were selected: corallite diameter (based on the mean of two greater diameters - corD), columellar diameter (based on the mean of two greater diameters - colD), septal number (sepN), thecal thickness - this measure includes the external wall and all the synapticulae (tecThick), columellar depth (depth), and the average distance between adjacent sampled calices (corDist)
(Figures 2 and 3). Septal number is a count and not a measure variable as the other characteristics. However, this data presented assumptions postulated by the Central Limit Theorem, which include a large number of independent random variables with finite mean and variance, not Bimodal and Poisson distribution and absence of zeros (Underwood 1997). Because of these criteria, we consider the septal number a continuous characteristic.

\section{Statistical analyses}

The statistical analyses were carried out only for the sites at which both species occurred (Paramana, Maria Guarda, Genipabu, Guarajuba and Itacimirim). One Discriminant Canonical Analyses was performed to evaluate the influence of intracolonial morphology and also the interspecific boundaries between S. stellata and S. radians. A total of six a priori groups were selected for analyses: top, middle and edge of $S$. stellata and top, middle and edge of S. radians. The
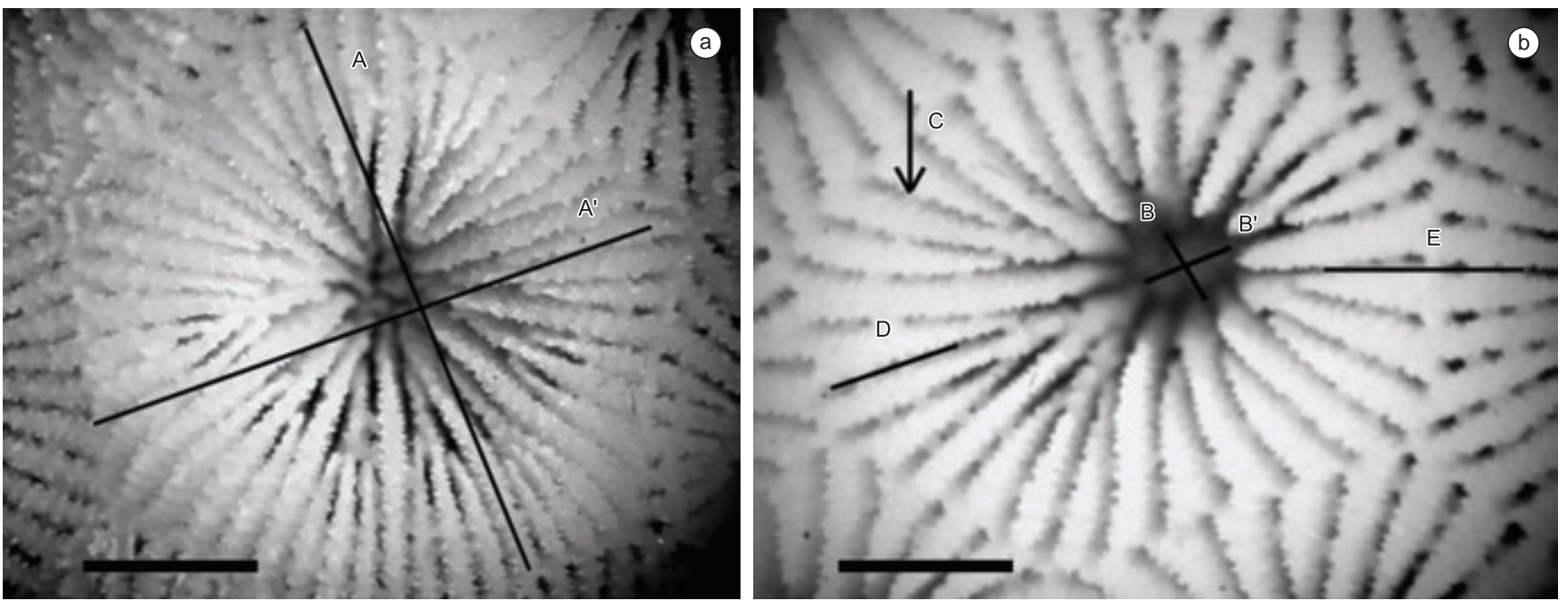

Figure 2. Mature corallites: (a) S. stellata and (b) S. radians (scale bar $=1 \mathrm{~mm}$ ). Adapted from Neves (2004). Measurements in the picture: (A+A'/2) corallite diameter; (B+B'/2) columellar diameter; (C) septal number; (D) theca thickness; (E) distance among corallites (this distance was measured as the mean distance to the theca of all neighbor corallites).

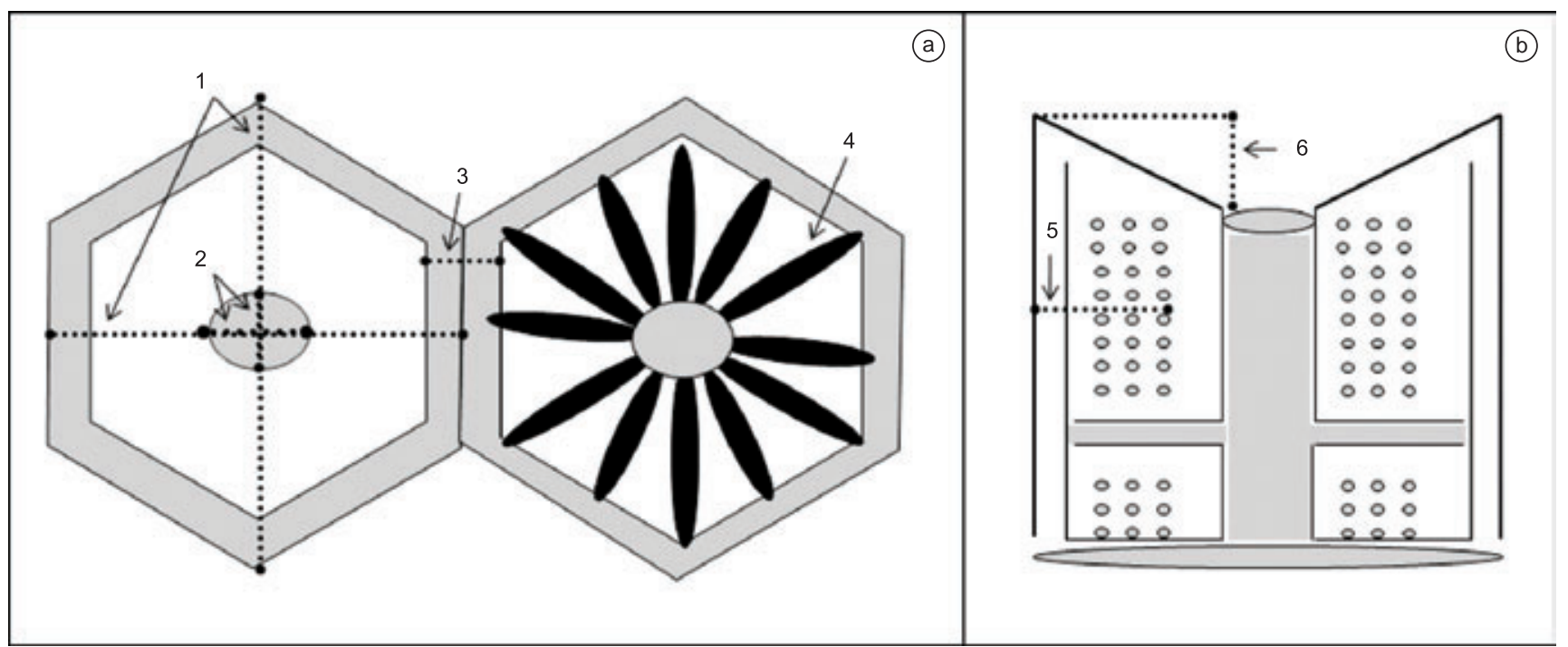

Figure 3. Measurements made on individual corallites: a) Cross-sectional view: (1) corallite diameter; (2) columellar diameter; (3) distance among corallites; (4) septal number. b) Longitudinal view: (5) theca thickness; (6) columellar depth. Adapted from Neves (2004). 
analysis was based in the average corallites of each region because of the difficulty to observe the great number of data on graph. The Kolmogorov-Smirnov test showed normal distribution for data. The Levene's test showed homoscedastic data. The Mann-Whitney U test with septal numbers was proceeded to confirm differences between both species once this trait presented a count characteristic. The $p$-level adopted in all tests was $\alpha=0.05$. Finally, a descriptive analysis was carried out with mean and standard deviation of measures from all corallites. The programs used were Statistica $7.0\left(\right.$ StatSoft $\left.^{\circledR}\right)$ and Excel $2007\left(\right.$ Microsoft $\left.^{\odot}\right)$.

\section{Results}

\section{Taxonomic data}

The analyses of the diagnostic characters associated with the number and conspicuity of the septal cycles of corallites (Neves 2004) resulted in the identification of 132 specimens of S. stellata and 24 specimens of $S$. radians (a total of 1200 and 120 corallites per species, respectively). Colonies of $S$. radians co-occurred with the endemic S. stellata in the following five localities: Paramana reefs (Frades I.) and Maria Guarda I., both in the BTS, and Guarajuba, Itacimirim and Praia do Forte reefs in the NS. Siderastrea radians have not been previously reported from the NS, although it has been previously cited from Frades I. (BTS) and the southern littoral (Neves 2004). In the other four populations localities sampled, only S. stellata was present and is clearly the more frequent and abundant congener of the pair (Table 1).

\section{Intracolonial variation}

The Discriminant Canonical Analyses showed significant differences among the groups (Wilks' Lambda $=0.55 ; \mathrm{F}$ $(30,1014)=5.46 ; p<0.0001)$. The characteristics that show differences among species were columellar diamenter (Wilks' Lambda $=0.6 ; \mathrm{F}(5,253)=4.78 ; \mathrm{p}<0.0001)$, septal number (Wilks' Lambda $=0.64 ; \mathrm{F}(5,253)=8.51 ; \mathrm{p}<0.0001)$ and columellar depth (Wilks' Lambda $=0.59 ; \mathrm{F}(5,253)=3.72 ; \mathrm{p}<0.0001)$. The CV1 axis explained $74 \%$ of the variation found and was primarily related to the characteristic septal number $(\mathrm{R}=0.75)$. The $\mathrm{CV} 2$ axis explained $23 \%$ of the variation and was primarily linked to the columellar diameter $(\mathrm{R}=0.53)$ and columellar depth $(\mathrm{R}=0.80)$ (Figure 4, Table 2). The

Table 2. Results of canonical discriminant analysis used to compare different regions between and within species. CV1 and CV2 represented approximately $74 \%$ and $23 \%$ of the variation, respectively. CV = canonical variable; $*=$ the most heavily weighted characteristics.

\begin{tabular}{lcc}
\hline & CV1 & CV2 \\
\hline CorD & -0.02 & -0.48 \\
ColD & -0.42 & $0.53^{*}$ \\
SepN & $0.75^{*}$ & 0.21 \\
TecThick & 0.52 & 0.21 \\
Depth & -0.03 & $0.80^{*}$ \\
CorDist & -0.02 & 0.01 \\
Eigenvalue & 0.53 & 0.16 \\
Cum. Prop. & 0.74 & 0.97 \\
\hline
\end{tabular}

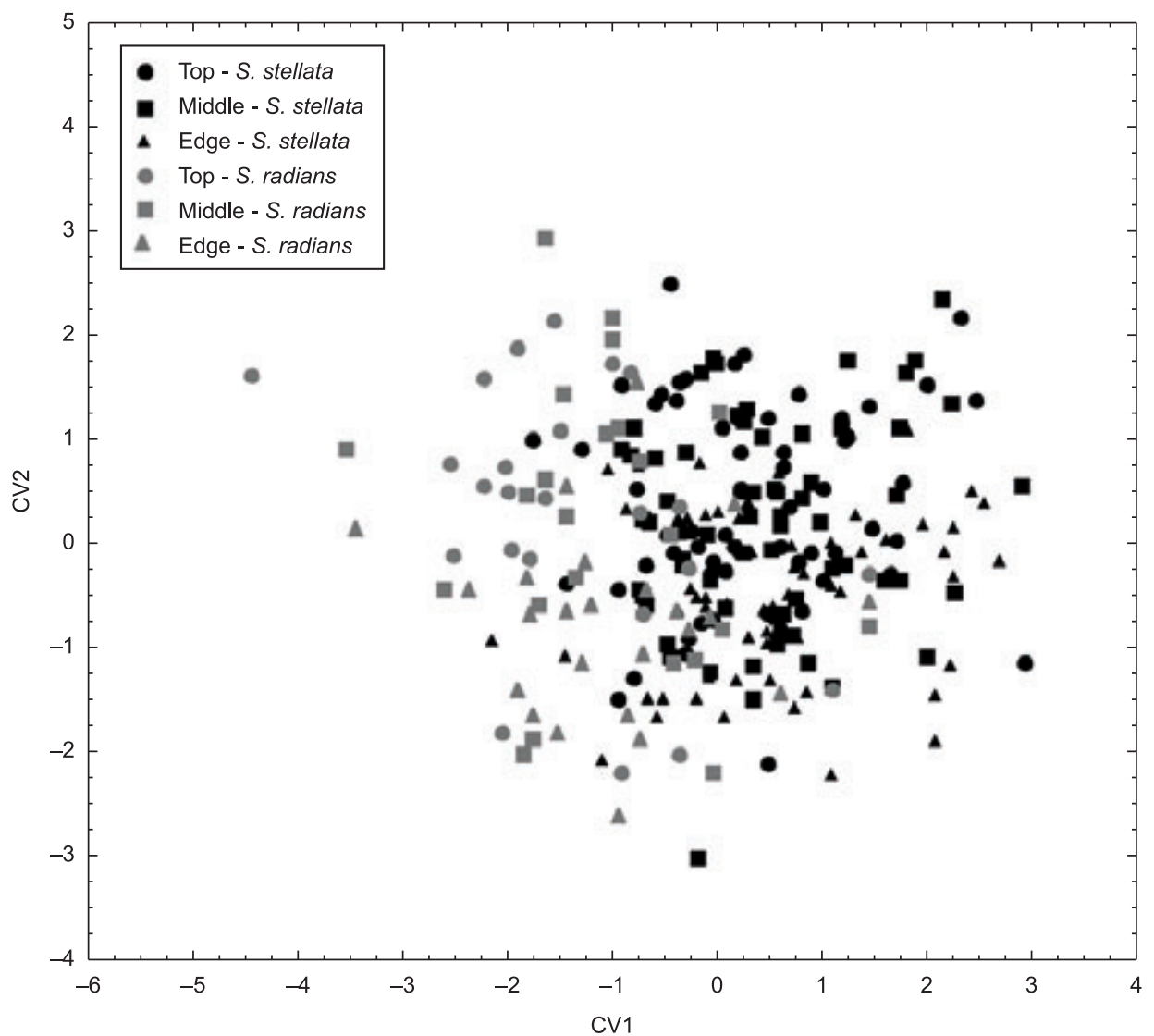

Figure 4. Graph of Canonical Discriminant Analysis comparing different regions within and between S. stellata and S. radians. 
additional $3 \mathrm{CVs}$ axis were not significant. The scatterplot (Figure 4) shows the data on $S$. stellata concentrated on the right side of the plot, corresponding to a greater number of septa, whereas the data on $S$. radians showed an opposite tendency. The Mann-Whitney U test based on septal numbers also showed a significant difference between both species $(\mathrm{U}=2201.5, \mathrm{p}<0.05)$. Thus, the results confirm that despite variation, septal number was the character that best distinguish the species. The other two important characteristics, related primarily to the second axis, were important for differentiating the regions for both species. The data for the edge region tended to be concentrated at the bottom of the plot and showed smaller values of the columellar diameter and depth in contrast to the other regions. This result can be confirmed with descriptive data form Table 4.

According to the squared Mahalanobis distance, intracolonial variation showed significant differences among the regions in both species (Table 3). For S. stellata, the top and middle were significantly different from the edge (Table 3). In general, the edge showed shallower corallites (Table 4; Figure 4). For S. radians, differences were found between the top and the edge. The edge corallites of this species were shallower than the top corallites (Table 4; Figure 4). Significant differences were found between species for each individual region (Table 3). Accordingly, similarities between regions for both species did not affect the differentiation between the species. Differences between species can also be observed in descriptive data that show greatest values for S. stellata (Table 4).

\section{Discussion}

\section{Taxonomy}

In contrast to the wide-ranging collections of $S$. stellata from Parcel Manuel Luiz in Maranhão state (Amaral et al. 2007) to Rio de Janeiro (Laborel 1969/70), intentional collections of S. radians have been conducted sparsely in geographically restricted areas in Brazil, such as Maragogi in Alagoas state, São José da Coroa Grande and Porto de Galinhas in Pernambuco state, Picãozinho and Ponta do Seixas in Paraíba state, Pirangi do Norte in Rio Grande do Norte state and Nova Almeida in Espírito Santo state (Neves et al. 2008). Thus, this study is the first to include both species, and extends the geographical range of $S$. radians to the BTS and NS. The occurrence of $S$. radians in the Southeastern Atlantic reveals a wider geographical distribution of the Caribbean species. Through this finding, one may suppose that the sympatric distribution of the Siderastrea populations has contributed to the misinterpretation of the taxonomic, ecological and biological data on these populations. Observing the 'excess' in the variation of S. stellata colonies, Laborel $(1967,1969 / 70)$ offered an early suggestion about the occurrence of $S$. radians in Brazil, but he has not pursued this topic. Relatively recent genetic studies (Forsman 2003, Neves et al. 2008) confirmed the occurrence of $S$. radians in Brazil and supported Vaughan (1919) and Laborel (1967, 1969/70) by considering $S$. stellata to be closely-related, yet distinct from the Caribbean congeners.

Despite irrefutable evidence of the sympatric occurrence of $S$. radians and $S$. stellata, there is a resistance to the adoption of the taxonomic morphometric analyses of the corallites traits for in situ studies. Visual recognition is not advisable because it may bias the results due to overestimation of $S$. stellata (the 'traditional' and most widespread Brazilian species). Therefore, the use of 'Siderastrea spp.' (see Cruz et al. 2008, Leão et al. 2008) has gained a degree of acceptance as a secure practice for reporting findings of the genus by those other than expert taxonomists without the inconvenience associated with the need to gather taxonomic data and the related analyses.

\section{Intracolonial variation}

A significant aspect of this study is that it represents the first morphological analysis to consider the sympatric occurrence of S. stellata and S. radians in Brazil from the perspective of a statistical approach. The results based on Discriminant Canonical Analysis show significant intracolonial variation in S. stellata and S. radians and reveal that this variation is related to differences between the edge of the corallum and other regions for both species. In particular, columellar diameter and columellar depth was significantly smaller in the edge region. Werner (1996) and Santos et al. (2004) do not discuss this issue. Neves (2004) also reported in higher frequency large and shallow corallites of $S$. stellata in the edge region, but did not perform any statistical analyses. Perhaps, this zone is affected by micro environmental characteristics as it is located closer to the substrate and is under continuous stress due to burial by sediment and competitive contact with surrounding organisms. Indeed, it is widely known that the environment has an important influence on the coral phenotype (Brakel 1977, Foster 1980, Todd et al. 2001, Pisapia et al. 2012). However, because of the absence of experimental analyses in this study, a few inferences about the influence of abiotic aspects can be done.

Although intracolonial variation has been found, the comparison of individual regions between $S$. stellata and $S$. radians shows significant differences (Table 3 ). The results showed that septal number was the most robust trait that separated both species while the others characters where less important (Tables 2 and 4). In a thesis, Neves (2004) suggested that $S$. radians and S. stellata, identified by genetic characteristics, should be differentiated by septal cycles: the first, has a reduction of the fourth cycle of the septum (S4) and the second has consistently complete S4. But, until this work, none morphological variation study with a greater number of specimens were done to confirm this hypothesis. Thus, considering the conservative pattern exhibited by septal number, this work confirms that it should be used to differentiate the species.

Originally, Verrill (1868) also refers to a complete fourth cycle in the diagnosis of the Brazilian Siderastrea. However, this description

Table 3. $P$-levels of $F$-statistic based on Squared Mahalanobis Distances among groups (top, middle and edge from S. stellata and S. radians). df = 6,253; $*=\mathrm{p}<0.05$.

\begin{tabular}{|c|c|c|c|c|c|c|}
\hline & $\begin{array}{c}\text { Top } \\
\text { S. stellata }\end{array}$ & $\begin{array}{c}\text { Middle } \\
\text { S. stellata }\end{array}$ & $\begin{array}{c}\text { Edge } \\
\text { S. stellata }\end{array}$ & $\begin{array}{c}\text { Top } \\
\text { S. radians }\end{array}$ & $\begin{array}{c}\text { Middle } \\
\text { S. radians }\end{array}$ & $\begin{array}{c}\text { Edge } \\
\text { S. radians }\end{array}$ \\
\hline \multicolumn{7}{|l|}{ Top - S. stellata } \\
\hline Middle - S. stellata & 0.89 & & & & & \\
\hline Edge - S. stellata & $0.01 *$ & $0.02 *$ & & & & \\
\hline Top - S. radians & $0.01 *$ & $0.01 *$ & $0.01 *$ & & & \\
\hline Middle - S. radians & $0.01 *$ & $0.01 *$ & $0.01 *$ & 0.90 & & \\
\hline Edge - S. radians & $0.01 *$ & $0.01 *$ & $0.01 *$ & $0.01 *$ & 0.05 & \\
\hline
\end{tabular}


Table 4. Descriptive statistics: mean, standard deviation and range of morphological variables analyzed for $S$. stellata and $S$. radians. Results include all populations. Metric values in millimeters $(\mathrm{mm})$. ( $\mathrm{x}=$ mean; s.d. = standard deviation).

\begin{tabular}{|c|c|c|c|}
\hline \multirow{2}{*}{ Traits } & \multirow{2}{*}{ Region } & S. stellata & S. radians \\
\hline & & $\mathbf{x} \pm$ s.d. & $\mathbf{x} \pm$ s.d. \\
\hline \multirow[t]{4}{*}{ CorD } & Top & $3,42 \pm 027$ & $3.04 \pm 0.38$ \\
\hline & Middle & $3,47 \pm 046$ & $3.14 \pm 0.35$ \\
\hline & Edge & $3,45 \pm 0.47$ & $3.14 \pm 0.41$ \\
\hline & Total & $3.44 \pm 0.47$ & $3.11 \pm 0.38$ \\
\hline \multirow[t]{4}{*}{ ColD } & Top & $0.47 \pm 0.10$ & $0.51 \pm 0.11$ \\
\hline & Middle & $0.45 \pm 0.10$ & $0.49 \pm 0.12$ \\
\hline & Edge & $0.43 \pm 0.09$ & $0.45 \pm 0.09$ \\
\hline & Total & $0.45 \pm 0.09$ & $0.48 \pm 0.11$ \\
\hline \multirow[t]{4}{*}{ SepN } & Top & $39 \pm 5.96$ & $30 \pm 4.65$ \\
\hline & Middle & $40 \pm 6.23$ & $31 \pm 4.91$ \\
\hline & Edge & $40 \pm 6.47$ & $30 \pm 4.79$ \\
\hline & Total & $39 \pm 6.35$ & $30 \pm 4.77$ \\
\hline \multirow[t]{4}{*}{ TecThick } & Top & $0.54 \pm 0.1$ & $0.49 \pm 0.10$ \\
\hline & Middle & $0.55 \pm 0.1$ & $0.51 \pm 0.10$ \\
\hline & Edge & $0.55 \pm 0.11$ & $0.51 \pm 0.10$ \\
\hline & Total & $0.60 \pm 0.11$ & $0.50 \pm 0.10$ \\
\hline \multirow[t]{4}{*}{ Depth } & Top & $1.36 \pm 0.27$ & $1.21 \pm 0.27$ \\
\hline & Middle & $1.32 \pm 0.27$ & $1.18 \pm 0.30$ \\
\hline & Edge & $1.16 \pm 0.26$ & $1.03 \pm 0.22$ \\
\hline & Total & $1.27 \pm 0.28$ & $1.13 \pm 0.27$ \\
\hline \multirow[t]{4}{*}{ CorDist } & Top & $1.09 \pm 0.21$ & $0.99 \pm 0.15$ \\
\hline & Middle & $1.12 \pm 0.21$ & $1.05 \pm 0.15$ \\
\hline & Edge & $1.11 \pm 0.22$ & $1.03 \pm 0.17$ \\
\hline & Total & $1.10 \pm 0.21$ & $1.02 \pm 0.15$ \\
\hline
\end{tabular}

may represent a questionable interpretation. In the comparison with $S$. radians in the diagnosis of the Brazilian Siderastrea, Verrill's description refers to a complete fourth cycle. In fact, S. stellata has a complete fourth cycle (S4). Nevertheless, its colonies can also include some corallites with an incomplete fourth cycle. It is distinctly different from $S$. radians, in which a complete S4 can never occur. Thus, $S$. stellata and $S$. radians cannot be confused because of the presence of an incomplete S4 in both species but should be distinguished by the absence of a complete S4 in S. radians. In addition, these considerations also reflect an interesting proposition: if the number of septa represents a conservative character, Siderastrea colonies could be identified with relative ease and security through their parts or fragments.

Although the distinction between the congeners was not hampered by intracolonial variation in this study (at least on the basis of the six variables applied), many authors consider that intracolonial variation can overwhelm the interspecific variation (see Foster 1985, Kaandorp \& Kübler 2001). In view of the continuous properties and the modular nature of the diagnostic features in Scleractinia, in fact, this aspect deserves attention (Todd 2008). However, intracolonial variation is one of the most neglected categories in taxonomic studies (BeltránTorres \& Carricart-Ganivet 1993, Jameson 1997, Amaral et al. 2002, Antonio-de-Souza \& Amaral 2002, Santos et al. 2004).

The study of morphological plasticity in reef-building corals is an important approach in many distinct disciplines, including taxonomy and phylogeny, ecology, biology, evolution and biogeography. The development of concise morphometric analyses of the distinct levels of variation from the most inferior (i.e, intracolonial) to the superior (interpopulational) categories provides a tool to understand the mechanisms of adaptation, habitat selection and gene connectivity.
Although intracolonial variation is not an obstacle to analysis in the studied siderastreids, criteria for this aspect of variation should be considered for the scleractinian determination of interspecific boundaries.

\section{Acknowledgements}

The authors are grateful for the support of the LABIMAR team (IB, UFBA), to MSc Igor Cruz (IB, UFBA) for collecting samples and to Marcelle Badaró (IB, UFBA) for outstanding help in the field. Special thanks are given to Ricardo Acácio (IMA - Setor Geoprocessamento) for assistance in preparing the map. This study was supported by the 'Programa de Pesquisa e Pós-Graduação/IGEOUFBA' with a scholarship and grants from the 'Fundação de Amparo à Pesquisa da Bahia’ (FAPESB) (BOL 1070/2005, APR0469/2005) to E. Neves, the 'Conselho Nacional de Desenvolvimento Científico e Tecnológico’(CNPq) (470336/2004-8 Edital Universal) to R. Johnsson, and the 'Programa Institucional de Bolsas de Iniciação Científica' (PIBIC/IB-UFBA 2006, 2007) to N. M. Menezes. The authors also would like to thanks the 'Programa de Pós-Graduação em Diversidade Animal-PPGDA at the Federal University of Bahia' and the 'American Journal Experts' for the English review.

\section{References}

AMADO-FILHO, G.M., SALGADO, L.T., REBELO, M.F., REZENDE, C.E., KAREZ, C.S. \& PFEIFFER W.C. 2008. Heavy metals in benthic organisms from Todos os Santos Bay, Brazil. Braz. J. Biol. 68: 95-100. http://dx.doi.org/10.1590/S1519-69842008000100013

AMARAL, F.M.D. 1994. Morphological variation in the reef coral Montastraea cavernosa in Brazil. Coral Reefs 13(4): 113-117. http:// dx.doi.org/10.1007/BF00300771

AMARAL, F.D., BROADHURST, M.K., CAIRNS, S.D. \& SCHLENZ, E. 2002. Sketelal morphometry of Millepora occuring in Brazil, including a previously undescribed species. Proc. Biol. Soc. Wash. 115: 681-695.

AMARAL, F.M.D., HUDSON, M.M., STEINER A.Q. \& RAMOS, C.A.C. 2007. New findings on corals and calcified hydroids of the Manuel Luiz Marine State Park (State of Maranhão, Northeast Brazil). Biota Neotropica 7: 1-9. http://dx.doi.org/10.1590/S1676-06032007000300008

ANTONIO-DE-SOUZA, C. \& AMARAL, F.D. 2002. Variação morfométrica de algumas espécies de corais Mussidae (Cnidaria, Anthozoa) do Brasil. Trop. Ocean. 30: 23-36.

BELTRÁN-TORRES, U. \& CARRICART-GANIVET, J.P. 1993. Skeletal morphologic variation in Montastraea cavernosa (Cnidaria: Scleractinia) at Isla Verde Coral Reef, Vera Cruz, México. Rev. Biol. Trop. 41: 559-562.

BEST, M.B., BOEKSCHOTEN, G.J. \& OOSTERBAAN, A. 1983. Species concept and ecomorph variation in living and fossil Scleractinia. Paleontogr. Am. 54: 70-79.

BEST, B.A. \& WINSTON, J.E. 1984. Skeletal strength of encrusting cheilostome bryozoans. Biol. Bull. 167: 390-409. http://dx.doi. org/10.2307/1541285

BRAKEL, W.H. 1977. Corallite variation in Porites and the species problem in corals. Proc. 3rd Intern. Coral. Reef. Symp. 1: 457-462.

BUCHANAN, J.B. 1954. The zoogeographical significance of the Madreporaria in the Gold coast, West Africa. Rev. Zool. Bot. Afr. 49: 84-88.

BUDD, A.F. 1990. Long term patterns of morphological variation within and among species of reef-corals and their relationship to sexual reproduction. Syst. Bot. 15: 150-165. http://dx.doi.org/10.2307/2419024

BUDD, A.F. \& GÚZMAN, H.M. 1994. Siderastrea glynni, a new species of scleractinian coral (Cnidaria, Anthozoa) from the Eastern Pacific. Proc. Biol. Soc. Wash. 107: 591-599.

CASTRO, C.B. \& PIRES, O.B. 2001. Brazilian coral reefs: what is already known and what is still missing. Bull. Mar. Sci. 69: 357-371. 
CELINO, J.J. \& QUEIROZ, A.F.S. 2006. Fonte e grau de contaminação por hidrocarbonetos policíclicos aromáticos (HPAs) de baixa massa molecular em sedimentos da Baía de Todos os Santos. Rev. Esc. Minas Ouro Preto 59: 265-270.

CHEVALIER, J.P. 1966. Contribution à l'étude des madreporaries des cotes occidentales de l'Afrique tropicale. Bull. I.F.A.N. 28: 1356-1405.

CHIAPPONE, M., SULLIVAN, K.M. \& LOTT, C. 1996. Hermatypic scleractinian corals of the southeastern Bahamas: a comparison to western Atlantic reefs systems. Carib. J. Sci. 32: 1-13.

CIRANO, M. \& LESSA, G.C. 2007. Oceanographic characteristics of Baía de Todos os Santos, Brazil. Rev. Braz. Geof. 25: 363-387. http://dx.doi. org/10.1590/S0102-261X2007000400002

COSTA, O.S.J., LEÃO, Z.M.A.N., NIMMO, M. \& ATTRILL, M.J. 2000. Nutrification impacts on coral reefs from Northern Bahia, Brazil. Hydrobiologia 440: 307-315. http://dx.doi.org/10.1023/A:1004104118208

COUTO, E.C.G., SILVEIRA, F.L. \& ROCHA, G.R.A. 2003. Marine biodiversity in Brazil: The current status. Gayana 67: 327-340.

CRUZ, I.C.S., KIKUCHI, R.K.P. \& LEÃO, Z.M.A.N. 2008. Use of the video transect method for characterizing the Itacolomis reefs, Eastern Brazil. Braz. J. Ocean. 56: 271-280.

DUERDEN, J.E. 1902. West Indian Madreporarian polyps. Nat. Acad. Sci. 8: 403-648.

FELIZZOLA, J.F., WAGENER, A.L.R., ALMEIDA, A.C. \& LIN, W.O. 2008. Butyltin speciation in sediments from Todos os Santos Bay (Bahia, Brazil) by GC-PFPD. Quím. Nova. 31: 89-93. http://dx.doi.org/10.1590/S010040422008000100019

FENNER, D.P. 1993. Species distinctions among several Caribbean corals. Bull. Mar. Sci. 53: 1099-1116.

FORSMAN, Z. 2003. Phylogeny and phylogeography of Porites and Siderastrea (Scleractinia: Cnidaria) Species in the Caribbean and Eastern Pacific; Based on the nuclear ribosomal ITS region. PhD Thesis, University of Houston.

FOSTER, A.B. 1977. Patterns of small-scale variation of skeletal morphology within the Scleractinian corals, Montastraea annularis and Siderastrea siderea. Proc. 3rd Int. Coral Reef Symp. 2: 409-415.

FOSTER, A.B. 1979. Phenotypic plasticity in the reef corals Montastrea annularis (Ellis and Solander) and Siderastrea Siderea (Ellis and Solander). J. Exp. Mar. Biol. Ecol. 39: 25-54.

FOSTER, A.B. 1980. Environmental variation in skeletal morphology within the Caribbean reef corals Montastraea annularis and Siderastrea siderea. Bull. Mar. Sci. 30: 678-709.

FOSTER, A.B. 1985. Variation within coral colonies and its importance for interpreting fossil species. Journ. Paleontol. 59: 1359-1381.

GATTUSO, J.P. 1991. Physiology and taxonomy of Scleractinian corals. A case study in the genus Stylophora. Coral Reefs 13: 49-56.

HAGEMAN, S.J. 2003. Complexity generated by unteraction of hierarchical modules in Briozoa. Integr. Comp. Biol. 43: 87-98. http://dx.doi. org/10.1093/icb/43.1.87

HOLST, I. \& GÚZMAN, H.M. 1993. Lista de corales hermatípicos (Anthozoa: Scleractinia; Hydrozoa: Milleporina) a ambos lados del Istmo de Panamá. Rev. Biol. Trop. 41(3): 871-875.

JAMESON, S.C. 1997. Morphometric analysis of the Poritidae (Anthozoa: Scleractinia) of Belize. Proc. 8th Int. Coral Reef Symp. 2: 1591-1596.

KAANDORP, J.A. \& KÜEBLER, J.E. 2001. The algorithmic beauty of seaweeds, sponges and corals. Springer-Verlag Heidelberg, New York.

KIKUCHI, R.K.P. 2000. Evolução dos recifes e das comunidades de corais hermatípicos da plataforma continental no norte da Bahia durante o Holoceno. PhD Thesis, Universidade Federal da Bahia, Brazil.

LABOREL, J. 1967. Les Peuplements de Madréporaires des Côtes Tropicales du Brésil. PhD. Thesis, University D’Aix-Marseille, French.
LABOREL, J. 1969/70. Madreporaires et hidrocoralliaires récifaux dês cotes brésiliennes: Systematique, écologie, réparttion verticale et géographique. Campagne de la Calypso au large dês cotes atlantiques de I'Amerique do Sud. Ann. Inst. Oceanogr. 47: 15-229.

LABOREL, J. 1974. West African reef corals an hypothesis on their origin. Proc. 2nd Int. Coral Reef Symp. 1: 425-443.

LAND, L.S., LANG, J.C. \& BARNES, D.J. 1975. Extension rate: a primary control on the isotopic composition of West Indian (Jamaican) scleractinian reef coral skeletons. Mar. Biol. 33: 221-233. http://dx.doi. org/10.1007/BF00390926

LEÃO, Z.M.A.N. 1986. Guia para identificação dos corais do Brasil. PPPG/ UFBA, Salvador.

LEÃO, Z.M.A.N., KIKUCHI, R.K.P. \& OLIVEIRA, M.D.M. 2008. Branqueamento de corais nos recifes da Bahia e sua relação com eventos de anomalias térmicas nas águas superficiais do oceano. Biota Neotrop. 8: 69-82. http://dx.doi.org/10.1590/S1676-06032008000300006

LOMBARDI, C., TAYLOR, P.D. \& COCITOS, S. 2008. Importance of zooidal polymorphs in the species-level taxonomy of bryozoans. J. Morphol. 269: 1475.

MAIDA, M. \& FERREIRA, B.P. 1997. Coral reefs of Brazil: an overview. Proc. 8th Int. Coral Reef Symp. 1: 263-274.

MILLER, K.J. 1994. Morphological variation in the coral genus Platygyra: environmental influences and taxonomic implications. Mar. Ecol. Prog. Ser. 110: 19-28. http://dx.doi.org/10.3354/meps110019

MILNE EDWARDS, H. \& HAIME, J. 1857. Histoire naturelle des coralliaires, polypes propement dits. Librairie Encyclopédique de Roret, Paris.

NEVES, E.G. \& DA SILVEIRA, F.L. 2003. Release of planula larvae, settlement and development of Siderastrea stellata Verrill, 1868 (Anthozoa: Scleractinia). Hydrobiologia 501: 139-147. http://dx.doi. org/10.1023/A:1026235832253

NEVES, E.G. 2004. Complexo Siderastrea: espécies distintas? Significado da variabilidade do gênero Siderastrea de Blainville, 1830 (Anthozoa: Scleractinia) no Brasil. PhD Thesis, University of São Paulo, Brazil.

NEVES, E.G., JOHNSSON, R., SAMPAIO, C. \& PICHON, M. 2006. The occurrence of Scolymia cubensis in Brazil: revising the problem of the Caribbean solitary mussids. Zootaxa 1366: 45-54.

NEVES, E.G., ANDRADE, S.C.S., LANG, F.S. \& SOLFERINI, V.N. 2008. Genetic variation and population structuring in two brooding coral species (Siderastrea stellata and Siderastrea radians) from Brazil. Genetica 132: 243-254. http://dx.doi.org/10.1007/s10709-007-9168-z

PISAPIA, C., HENNIGE, S.J., HAAPKYLÄ, J., MATTEUCCI, R. \& SMITH, D.J. 2012. Morphological changes in polyp structure of massive coral species in clear and turbid waters. Bull. Mar. Sci. 88: 183-191. http:// dx.doi.org/10.5343/bms.2010.1086

SANTOS, M.G., AMARAL, F.D., HERNANDEZ, M.I.M., KNOWLTON, N. \& JARA, J. 2004. Variação morfológica de Favia gravida (Verrill, 1868) e Siderastrea stellata Verrill, 1868 (Cnidaria, Scleractinia): Aspectos esqueléticos. Bol. Mus. Nac. Rio J. Zool. 517: 1-9.

SOONG, K. \& LANG, J.C. 1992. Reproductive integration in reef corals. Biol. Bull. 183: 418-431. http://dx.doi.org/10.2307/1542018

SZMANT, A.M. 1986. Reproductive ecology of Caribbean reef corals. Coral Reefs 5: 43-53. http://dx.doi.org/10.1007/BF00302170

TODD, P.A., SANDERSON, P.G. \& CHOU, L.M. 2001. Morphological variation in the polyps of the scleractinian coral Favia speciosa (Dana) around Singapore. Hydrobiologia 444: 227-235. http://dx.doi. org/10.1023/A:1017570100029

TODD, P.A. 2008. Morphological plasticity in Scleractinians corals. Biol. Rev. Camb. Philos. Soc. 83: 315-337. http://dx.doi.org/10.1111/j.1469185X.2008.00045.X

UNDERWOOD, A.J. 1997. Experiments in ecology: their logical design and interpretation using analysis of variance. Cambridge university press, Cambridge. 
VAUGHAN, T.W. 1919. Fossil corals from Central America, Cuba, and Porto Rico, with an account of the American Tertiary, Pleistocene, and recent coral reefs. Bull. Smith. Inst. 103: 189-524.

VAUGHAN, T.W. \& WELLS, J.W. 1943. Revision of the suborders, families, and genera of the Scleractinia. Geol. Soc. Am. Spec. Pap. 44: 1-343.

VERON, J.E.N. 1995. Corals in space and time: The biogeography and evolution of the Scleractinia. UNSW Press, Sydney.

VERRILL, A.E. 1868. Notice of the corals and echinoderms collected by prof. C.F. Hartt, at the Abrolhos Reefs, province of Bahia, Brazil. Trans. Conn. Acad. Arts. Sci. 1: 351-37.
WEIL, E. \& KNOWLTON, N. 1994. A multi-character analysis of the Caribbean coral Montastraea annularis (Ellis and Solander, 1786) and its two sibling species, $M$. faveolata (Ellis and Solander, 1786) and $M$. franksi (Gregory, 1895). Bull. Mar. Sci. 55: 151-175.

WERNER, T.B. 1996. Recent Zooxanthellate Corals (Order: Scleractinia) from Ascension and St. Helena Is., South Atlantic, with a summary of their geographic distribution in the Atlantic Ocean. PhD Thesis, University of Maryland, USA.

ZLATARSKI, V.N. \& ESTALELLA, N.M. 1982. Les Scleractiniaires de Cuba avec des données sur les organismes associes. Editora Acadie Bulgare Sciences, Sofia. 